\title{
Clinical and epidemiological profile of patients with multiple sclerosis in Uberaba, Minas Gerais, Brazil
}

\author{
Sônia Beatriz Félix Ribeiro', Danilo Fonseca Maia², \\ João Batista Ribeiro ${ }^{3}$, Fabrízio Antônio Gomide Cardoso ${ }^{4}$, Cátia Silva ${ }^{5}$
}

\begin{abstract}
Multiple sclerosis (MS) is an immune-mediated disease that affects the central nervous system. Clinical presentation and prevalence vary widely around the world. Objective: To describe the clinical and epidemiological aspects of patients with MS in Uberaba (MG). Method: We conducted a transversal descriptive study, with data analysis of 35 patients with MS. Results: Prevalence of MS was 12.5 cases/100,000 inhabitants, with a predominance in females (71.4\%) and Caucasoid (85.7\%). The current average age was (43.8 ys). The most common initial symptom was sensory (40\%), followed by optical neuritis (25.7\%). Expanded Disability Status Scale average score was 2.4. The relapsing-remitting form was predominant (88.6\%), most $(74.3 \%)$ were on immunomodulatory treatment and (40\%) had college education. Conclusion: Prevalence of MS in Uberaba (MG) is considered average in accordance to Kurtzke and Page and clinical features are consistent with most Brazilian studies.
\end{abstract}

Key words: multiple sclerosis, epidemiology, prevalence.

Perfil clínico e epidemiológico dos pacientes com esclerose múltipla na cidade de Uberaba (MG), Brasil

\section{RESUMO}

A esclerose múltipla (EM) é uma doença imunomediada que acomete o sistema nervoso central. Seus aspectos clínicos e prevalência variam consideravelmente em todo o mundo. Objetivo: Descrever a prevalência, os aspectos clínicos e epidemiológicos dos pacientes com EM na cidade de Uberaba (MG). Método: Realizado estudo descritivo transversal, com análise dos dados de 35 pacientes com EM. Resultados: A prevalência de EM foi de 12,5 casos/100.000 habitantes, com predomínio no sexo feminino (71,4\%) e etnia caucasóide (85,7\%), idade média atual de 43,8 anos. Do total, 40 possuem curso superior. O sintoma inicial mais frequente foi o sensitivo (40\%), seguido de neurite óptica $(25,7 \%)$. A média dos escores da Escala de Status de Incapacidade Expandida foi de 2,4 . A forma evolutiva recorrente-remitente foi predominante $(88,6 \%)$, com $(74,3 \%)$ dos pacientes em uso de imunomodulador. Conclusão: A prevalência de EM no município de Uberaba (MG) é considerada média, de acordo com Kurtzke e Page. Os aspectos clínicoepidemiológicos estão em consonância com a maioria dos estudos brasileiros.

Palavras-chave: esclerose múltipla, epidemiologia, prevalência.

\section{Correspondence}

Sônia Beatriz Félix Ribeiro

Av. Getúlio Guraritá s/n

38025-440 Uberaba MG - Brasil

E-mail: neurologia@uftm.edu.br

Received 3 April 2010

Received in final form 29 September 2010 Accepted 6 October 2010
Multiple sclerosis (MS) is an inflamatory demyelinating disease affecting the central nervous system (CNS), with presumed autoimmune etiology $y^{1,2}$. It affects mostly young adults, leading to the emergence of various signs and symptoms, often disabling, with no estimated duration and possible remission ${ }^{2}$. The neuro-

${ }^{1} \mathrm{PhD}$ in Neurology, Department of Neurology, Federal University of Triangulo Mineiro (UFTM), Uberaba MG, Brazil; ${ }^{2}$ Clinical Neurologist and Fellow in Clinical Neurophysiology at the University of São Paulo (USP), São Paulo SP, Brazil; ${ }^{3}$ Master in Psychology, Psychology Department, UFTM; ${ }^{4}$ Master in Physiotherapy, Department of Physiotherapy, UFTM; ${ }^{5}$ Master in Social Service, Department of Social Service, UFTM. 
logical symptoms of this disease are manifestations of inflammatory reaction of the central nervous system (CNS) and, over the long term they reflect the degenerative aggression against a variety of functional neurological systems ${ }^{3}$. Genetic and environmental factors are unequivocally related to susceptibility and expression of the disease $\mathrm{e}^{4}$. MS displays an unimodal distribution between 20-40 years of age, with a higher incidence in females and Caucasians ${ }^{2,5}$.

The prevalence of MS varies considerably around the world, being higher in regions located between the parallels 44 and $64 \mathrm{~N}$. Areas considered as of high prevalence are those with more than 30 cases per 100,000, average prevalence areas with 5 to $30 / 100,000$, and low prevalence areas less than $5 / 100,000^{2,3,5-7}$. MS seems to be a relatively rare disease in South American in comparison with Northern hemisphere Countries ${ }^{2,6}$. Brazil is considered a low prevalence area, however, there are medium-prevalence areas, as shown in studies from cities such as São Paulo ${ }^{8}$, Belo Horizonte ${ }^{9}$, Santos ${ }^{10}$, Botucatu ${ }^{11}$ and Sorocaba ${ }^{12}$.

Uberaba is located in the state of Minas Gerais, with a latitude of $19^{\circ} 45^{\prime} 27$ West and longitude of $47^{\circ} 55^{\prime} 36$. The climate in this region according to Köppen's raking is AW, that is characterized by two seasons: a cold and dry winter and a hot and wet summer, with an average annual temperature of $23.2^{\circ} \mathrm{C}$, an annual average humidity of $64 \%$ and an altitude of 764 meters $^{13}$. According to the Brazilian Institute of Geography and Statistics (IBGE) ${ }^{13}$, the city occupies $256 \mathrm{Km}^{2}$ of urban area, with a total area of $4,512.14 \mathrm{Km}^{2}$. Its population is of 287,760 inhabitants, with an annual growth rate of $1.96 \%$, urbanization rate of $96.9 \%$, a population density of 55.4 inhabitants $/ \mathrm{Km}^{2}$, a HDI (Human Development Index) of 0.834, and a life expectancy of 73 years $^{13}$. The main economic activities are industry, commerce, agriculture and cattle breeding $(\mathrm{IBGE})^{14}$. The city has 2 teaching hospitals, 6 private hospitals, 2 radiological clinics with MRI, 2 CSF laboratories, 1004 physicians, of which 16 are neurologists and 6 neurosurgeons.

\section{METHOD}

This is a transversal descriptive study, with patients from the Grupo de Estudo e Pesquisa em Esclerose Múltipla (GEPEM), outpatients from the Universidade Federal do Triângulo Mineiro (UFTM) and from the Associação Uberabense de Amigos e Portadores de Esclerose Múltipla (AUAPEM), private clinics, radiological clinics, and data from Uberaba's Heath Department ${ }^{13 .}$

A cross-sectional study was held from August to December 2008. The patients were classified in accordance with the criteria of Poser $^{3}$ and McDonald ${ }^{15}$ and only those with defined multiple sclerosis were registred.

Data was collected according to the method proposed by LACTRIMS (Latin American Committee for Treatment and Research in Multiple Sclerosis) ${ }^{16}$ from patients' medical files, with prior knowledge and signature of a term of clarification and free consent. This study was

Table 1. Distribution of epidemiological data from patients with multiple sclerosis in Uberaba (MG).

\begin{tabular}{|c|c|c|c|c|c|}
\hline \multirow[b]{3}{*}{ Epidemiological data } & \multicolumn{4}{|c|}{ Gender } & \multirow[b]{3}{*}{ Total } \\
\hline & \multicolumn{2}{|c|}{ Male } & \multicolumn{2}{|c|}{ Female } & \\
\hline & $\mathrm{N}$ & $\%$ & $\mathrm{~N}$ & $\%$ & \\
\hline \multicolumn{6}{|l|}{ Current age } \\
\hline$>20$ years & 1 & 10 & - & - & 1 \\
\hline 20-30 years & 1 & 10 & 6 & 24 & 7 \\
\hline $31-40$ years & 3 & 33.3 & 4 & 16 & 7 \\
\hline 41-50 years & 1 & 10 & 9 & 36 & 10 \\
\hline $51-60$ years & 2 & 20 & 3 & 12 & 5 \\
\hline$>60$ years & 2 & 20 & 3 & 12 & 5 \\
\hline \multicolumn{6}{|l|}{ Ethnic group } \\
\hline White & 7 & 70 & 23 & 92 & 30 \\
\hline Black & - & - & - & - & - \\
\hline Pheodermic & 3 & 30 & 2 & 8 & 5 \\
\hline \multicolumn{6}{|l|}{ Level of education } \\
\hline Elementary school & 4 & 40 & 3 & 12 & 7 \\
\hline High school & 3 & 33.3 & 11 & 44 & 14 \\
\hline University studies & 3 & 33.3 & 11 & 44 & 14 \\
\hline
\end{tabular}

Source: patients with MS-GEPEM-UFTM, AUAPEM, private clinics. 
Table 2. Distribution of epidemiological data from patients with multiple sclerosis in Uberaba (MG).

\begin{tabular}{|c|c|c|c|c|c|}
\hline \multirow[b]{3}{*}{ Epimiological data } & \multicolumn{4}{|c|}{ Gender } & \multirow[b]{3}{*}{ Total } \\
\hline & \multicolumn{2}{|c|}{ Male } & \multicolumn{2}{|c|}{ Female } & \\
\hline & $\mathrm{N}$ & $\%$ & $\mathrm{~N}$ & $\%$ & \\
\hline \multicolumn{6}{|l|}{ Disease duration } \\
\hline$<1$ year & 2 & 20 & - & - & 2 \\
\hline 1 a 5 years & 5 & 50 & 13 & 52 & 18 \\
\hline 6 a 10 years & 1 & 10 & 9 & 36 & 10 \\
\hline$>10$ years & 2 & 20 & 3 & 12 & 5 \\
\hline \multicolumn{6}{|l|}{ Clinical forms } \\
\hline Relapsing remitting & 9 & 90 & 22 & 88 & 31 \\
\hline Secondary progressive & - & - & 2 & 8 & 2 \\
\hline Primary progressive & 1 & 10 & 1 & 4 & 2 \\
\hline \multicolumn{6}{|l|}{ Initial symptom } \\
\hline Optical neuritis & 1 & 10 & 8 & 32 & 9 \\
\hline Brainstem/cerebellum & 2 & 20 & 3 & 12 & 5 \\
\hline Sensory & 4 & 40 & 10 & 40 & 14 \\
\hline Motor & 1 & 10 & 2 & 8 & 3 \\
\hline Others & 2 & 20 & 2 & 8 & 4 \\
\hline
\end{tabular}

Source: patients with MS-GEPEM-UFTM, AUAPEM, private clinics.

approved by the Research Ethics Committee of UFTM, under protocol number 884/2007. The epidemiological variables were: gender, age, ethnicity, initial symptom, clinical forms, use of immunomodulators, elapsed time of disease, EDSS (expanded disability status scale) ${ }^{17}$, and level of education.

\section{RESULTS}

A total of 35 patients with MS were identified in Uberaba, resulting in a prevalence of 12.5 cases/100,000 inhabitants. Among these 35 patients, 25 (71.4\%) were female, ratio $2.5: 1 ; 30$ (85.7\%) White; an mean age at onset was 43.8 years for females and 44 for males. Regarding level of education, 7 patients (20\%) completed elementary school, 14 (40\%) high school and 14 (40\%) concluded university studies. The epidemiologic data are described on Table 1. At the time of diagnosis, the average age was 37.3 years for males and 37.4 for females. Mean disease duration was of 6.7 years, ranging from 3 months to 35 years. The average current EDSS was 2.4, with values between 1 and 7.5. Details about data related to the disease are found in Table 2.

\section{DISCUSSION}

In Uberaba the prevalence of MS is of 12.5 cases/ 100,000 inhabitants, configurating an average prevalence in accordance to findings by Kurtzke ${ }^{7}$, and in agreement with studies conducted in São Paulo ${ }^{8}$, Belo Horizonte ${ }^{9}$, Santos $^{10}$. Botucatu ${ }^{11}$ and Sorocaba ${ }^{12}$. However, this prev- alence is above other estimates ${ }^{18}$. The reasons for this discrepancy between Brazilian regions may be linked to genetic, environmental, ethnic, and socio-economical factors and differences in access to health services. Besides, MS is a disease whose diagnosis requires an extensive list of complementary tests, neurological expertise, in addition to a vast list of differential diagnosis. All these features underscore the importance of epidemiological studies and the necessity for reference centers, in order to implement more reliable diagnoses and to demonstrate as closely as possible the real prevalence of MS. The medium age at the time of diagnosis for both genders is above averages obtained in similar studies ${ }^{19,20}$.

The White ethnic group was predominant, in agreement with most Brazilian statistics ${ }^{21,22}$, except in a survey conducted in Recife, Brazil, in which the African Brazilian ethnic group was responsible for (93.3\%) of cases ${ }^{18}$. In this aspect, classifying patients according ethnic factors is a difficult task because of extensive racial miscegenation in Brazilian communities as well as the existence of many classifications.

The most common initial symptom was sensory (40\%), followed by optical neuritis $(25.7 \%)$ and brainstem/cerebellum symptoms (14.3\%), in accordance to other studies ${ }^{23}$. As to educational status, $40 \%$ concluded university studies, an intriguing fact in a country where the vast majority does not even finish high school. The evolution form relapsing remitting occurred in most (88.6\%) patients, in accordance to Brazilian and inter- 
national literature ${ }^{24}$. Out of all patients with MS in this study, $25.7 \%$ were not receiving immunomodulatory treatment. There are some possible reasons for this apparent delay in the implementation of treatment, considering that the ultimate decision on beginning medication is also made by the patient, after presentation of current medical knowledge. This study aimed to demonstrate the epidemiological profile of patients with MS in Uberaba, where there is a reference center in MS (GEPEM) and good quality public and private health system when compared to other less developed regions in Brazil, facilitating diagnoses of diseases that require expensive complementary tests and medical specialists.

\section{REFERENCES}

1. Comi G, Filipi M, Wolinski JS. European/Canadian Multicenter, doubleblind, randomized, placebo controlled study of the effects of glatiramer acetate on magnetic resonance imaging-measured disease activity and burden in patients with relapsing multiple sclerosis. Ann Neurol 2001; 49:290-297.

2. Noseworthy JH, Lucchinetti C, Rodriguez M, Weinshenker BG. Multiple sclerosis. N Engl J Med 2000;343:938-951.

3. Poser CM, Paty DW, Scheinberg $L$, et al. New diagnostic criteria for multiple sclerosis: guidelines for research protocols. Ann Neurol 1983;3:227-231.

4. Kantarci $\mathrm{OH}$, de Andrade $M$, Weinshenker BG. Identifying disease modifying genes in multiple sclerosis. J Neuroimmunol 2002;123:144-159.

5. Callegaro D. Epidemiology aspects. In: Tilbery CP (Ed). Multiple sclerosis in Brazil: clinical and therapeutic aspects. São Paulo: Atheneu, 2005:13-15.

6. Rosati G. The prevalence of multiple sclerosis in the world: an update. Neurol Sci 2001:22:117-139.

7. Kurtzke JF. A reassessment of the distribution of multiple sclerosis: part I and II. Acta Neurol Scand 1975:51:137-157.

8. Callegaro D, Goldbaum M, Morais L, et al. The prevalence of multiple sclerosis in the city of São Paulo, Brazil, 1997. Acta Neurol Scand 2001;104: 208-213.

9. Lana-Peixoto MA, Frota ERC, Campos GB, et al. The prevalence of multiple sclerosis in Belo Horizonte, Brazil. Multiple Sclerosis 2002;8(Suppl):S38.
10. Fragoso YD, Peres M. Prevalence of multiple sclerosis in the city of Santos SP. Rev Bras Epidemiol 2007:10:479-482.

11. Rocha F, Herrera LC, Morales RR. Multiple sclerosis in Botucatu, Brazil: a population study. Multiple Sclerosis 2002;8(Suppl):S41.

12. Gama PD, Trigo LX, Andrade CRR, Sala CR. Epidemiological study of multiple sclerosis in the city of Sorocaba, Brazil. Arq Neuropsiquiatr 2004;62(Suppl1):S13.

13. BRASIL. Ministério do Planejamento, Orçamento e Gestão. Instituto Brasileiro de Geografia e Estatística. Contagem Populacional (IBGE-2007). Available at: www.sidra.ibge.gov.br/bda/popul Accessed January 18/2009.

14. Instituto Brasileiro de Geografia e Estatística(IBGE). Dados demográficos Prefeitura Municipal do Município de Uberaba-MG - 2008: Available at www.uberaba.mg.gov.br Accessed january/18/2009.

15. Polman $\mathrm{CH}$, Reingold SC, Edan G, et al. "Diagnostic criteria for multiple sclerosis: 2005 revisions to the "McDonald Criteria. Ann Neurol 2005; 58:840-846.

16. Latin American Committee for Treatment and Research in Multiple Sclerosis LACTRIMS - Metodologia para a realização de estudo epidemiológico. Available at: www.lactrims.org Accessed August/20/2007.

17. Kurtzke JF. Rating neurologic impairment in multiple sclerosis: an expanded disability status scale (EDSS). Neurology 1983;33:1444-1452.

18. Ferreira MLB, Machado MIM, Vilela ML, et al. Epidemiology of 118 cases of multiple sclerosis after 15 years of follow-up on the reference Center of Hospital of Restauração, Recife, Pernambuco, Brazil. Arq Neuropsiquiatr 2004:62:1027-1032.

19. Arruda WO, Scola RH, Teive HAG, Werneck LC. Multiple sclerosis: report on 200 cases from Curitiba, Southern Brazil and comparison with other Brazilian series. Arq Neuropsiquiatr 2001;59:165-170.

20. Lana-Peixoto MA, Lana-Peixoto MI. Is multiple sclerosis in Brazil and Asia alike? Arq Neuropsiquiatr 1992;50:119-125.

21. Oliveira EML, Annes M, Oliveira ASB, Gabbai AA. Multiple sclerosis: clinical survey of 50 patients followed at the Department of Neurology UNIFESPEPM. Arq Neuropsiquiatr 1999;57:51-55

22. Tilbery CP, Felipe E, Moreira MA, et al. Interferon beta $1^{\text {a }}$ in multiple sclerosis: 1-year experience in 62 patients. Arq Neuropsiquiatr 2000;58: 452-459.

23. Santos EC, Yokota Mitiko, Dias NFR. Multiple sclerosis: study of patients with relapsed-remitting form registered at Minas Gerais Secretary State Of Health. Arq Neuropsiquiatr 2007;65:885-888.

24. Moreira, MA, Felipe E, Mendes, MA, Tilbery, CP. Multiple sclerosis. Descriptive study of the initial forms in 302 cases. Arq Neuropisiquiatr 2000;58: 460- 466. 